Besides irrigation surveys, fertility, land-use and soil-conservation surveys have been made in various parts of India, and this work is being extended. A basic system of classification for Indian soils is still lacking, and much field-work will have to be done before such a system can be devised. An All-Indian regional soil survey has been planned, and soil classes will be determined on a soil and geomorphological basis, with complementary chemical and physical determinations in the laboratory. Four regional centres are proposed in alluvial, black, red and laterite areas. The Indian Agricultural Research Institute now provides a two-year training course in soil survey.

\section{Year Book of the Physical Society, 1955}

ThE miscellaneous items which were previously published in the December issues of the Physical Society's Proceedings are now being published by the Society separately, entitled "Year Book of the Physical Society". The first such "Year Book", that for 1955, has been published (pp. 92; 10s.) and contains the following items: the texts of the 1955 presidential address, the 1954 Rutherford Memorial Lecture, the 39th Guthrie Lecture and the 18th Thomas Young Oration; abstracts of the lectures delivered by the recipients of the 31st Duddell Medal and the 10th Charles Vernon Boys Prize; obituary notices of five Fellows including Albert Einstein and G. F. C. Searle; and the report of the Council of the Society for 1954. In his Rutherford Lecture, Prof. P. M. S. Blackett describes his impressions of Rutherford and in particular refers to Rutherford's attitude to research and to the technical methods by which Rutherford achieved his astonishing output of important discoveries. He then discusses the problem of the proper relationship between the training of students in experimental technique and in theoretical knowledge, the difference between the present practice in British and American universities, and finally advances the practical solution of giving the experimental research worker an intense theoretical education in that part of theoretical physics which is narrowly centred on his experimental investigation. The Guthrie Lecture, entitled "Magnetism in Retrospect and Prospect", which was delivered by Prof. E. C. Stoner, consists of a survey of the advance in knowledge and understanding of the magnetic properties of matter during the past thirty years. Some of the outstanding experimental and theoretical prob. lems are indicated, together with suggestions as to the kinds of experimental investigations required to elucidate the particular difficulties associated with metals. Tho basic data of colour-matching are the subject of the Thomas Young Oration, delivered by W. S. Stiles, of the National Physical Laboratory, Teddington, and a new determination of the colourmatching functions is described.

\section{The Physics of Gas Flow at Very High Speeds}

THe Summer Meeting of the Physical Society will be held this year in the University of Manchester during July 16-17, and will be concerned with the flow of air and other gases at speeds so high that changes in kinetic energy are comparable with the energy required to produce interesting physical changes, such as dissociation, ionization and sub. stantial emission of radiation. The implications for the aerodynamics of man-made projectiles travelling at extreme speeds, and also of meteors, will be included in the discussion. The shock tube will be discussed at length, both as regards design and instrumentation for use with very strong shock waves, and in connexion with the results so far discovered by its use. Prof. M. J. Lighthill, Department of Mathematics, University of Manchester, is organizing the sessions. Among those taking part in this meeting are: Mr. J. G. Davies (Jodrell Bank Experimental Station); Dr. Wayland Griffith (Palmer Physical Laboratory, Princeton University); Dr. D. W. Holder and staff (High-speed Section, Aerodynamics Division, National Physical Laboratory); Prof. M. J. Lighthill (Manchester); Prof. N. F. Mott (Cambridge) ; H. K. Zienkiewicz (Manchester). Non-members of the Society will be able to attend the meeting; inquiries should be addressed to the Physical Society, 1, Lowther Gardens, Prince Consort Road, London, S.W.7, marked for the attention of Miss Miles.

\section{Commonwealth Fund Grants for Medical Education in the United States}

THE Commonwealth Fund, New York, has recently given grants of $4,850,000$ dollars to seven university medical schools in the United States for use in whatever ways the schools consider most effective to improve their programmes of medical education. These grants, which are in addition to the sums expended for specific medical education projects during the fiscal year 1955-56, have been drawn from the Fund's capital assets and current income, and they bring to a total of $12,600,000$ dollars the amount of such gifts made by the Fund since November 1955 to help the medical schools in the United States. The schools receiving the new grants are: Albany Medical College of Union University, 500,000 dollars ; George Washington University School of Medicine, 500,000 dollars; University of Pennsylvania School of Medicine, 500,000 dollars; Boston University School of Medicine, 600,000 dollars ; University of Rochester School of Medicine and Dentistry, 750,000 dollars; Johns Hopkins University School of Medicine, $1,000,000$ dollars; and Stanford University School of Medicine, 1,000,000 dollars. During recent years the primary interests of the Commonwealth Fund have been in the field of health, particularly in medical education, medical research and community health services.

\section{Institute of Biology: London Branch}

THE London Branch of the Institute of Biology held its annual conversazione on May 10 at the South-West Essex Technical College, Walthamstow, by courtesy of the principal of the College, Dr. H. Lowery. Guests were received by Dr. Lowery and Dr. H. O. J. Collier, president of the London Branch. Many biological topics were represented, from seals to bacteria: anatomy, ecology, ethology, microbiology, parasitology, pharmacognosy, physiology and biochemistry, and genetics were all represented. An interesting section was grouped together under "Improvisation and Gadgetry" ; this was a valuable idea. The research worker is so often helped if he or one of his colleagues is versed in the art of gadgetmaking. It is often not simply' a matter of 'making do', but of constructing something to do a job when no suitable apparatus already exists. Films and slides on four different topics were exhibited. It is customary for a guest society to be invited to make an exhibit; this year it was the Royal Institution, which displayed various historic documents and 